ARTIKEL

Filsafat Politik Nurcholish Madjid

Muhammad Saleh Tajuddin

Kedaulatan Rakyat dalam Pemikiran Filsafat

Politik Montesquieu

Fajrul Ilmy Darussalam \& Andi Batara Indra

$189-204$

Politik Multikulturalisme: Sebuah Gerakan Keadilan

dan Kesetaraan

Muhaemin Latif

$205-229$

Kompetisi, Kompromi dan Coalition Agreement: Berebut

Kursi Wakil Gubernur DKI Jakarta di Tengah

Kontestasi Pemilihan Presiden 2019

Mahpudin \& Fransisca Mega Lestari

$230-259$

Kegagalan Keterlibatan Politik: Dari Kesenjangan Digital

Menuju Kesenjangan Demokrasi

Fairuz Arta Abhipraya \& Bambang Eka Cahya Widodo

Mobilisasi Massa Kemenangan Kolom Kosong Pada Pemilihan Walikota Makassar Tahun 2018

Gustiana Kambo

Kinerja Komisi Pemilihan Umum Kota Makassar dalam

Melindungi Hak Pilih Warga di Tengah

Pandemi COVID-19

Dyahwanti Sulistyowati, Muhammad, Sukri \& Ariana

Isu Pemekaran Wilayah Sebagai Komoditas Politik Dalam Masyarakat

To Pulo di Kepulauan Selayar

Dwi Indriani \& Sudarmono

Penanganan Konflik Melalui Keamanan di Kalimantan Barat 


\title{
MOBILISASI MASSA KEMENANGAN KOLOM KOSONG PADA PEMILIHAN WALIKOTA MAKASSAR TAHUN 2018
}

\author{
Gustiana Kambo \\ Universitas Hasanuddin \\ Email: gustianakambo@yahoo.com
}

\begin{abstract}
Abstrak
Penelitian ini bertuiuan untuk mengambarkan kemenangan kolom kosong pada pemilihan walikota Makassar tahun 2018. Penelitian ini menggunakan metode kualitatif dengan jenis studi kasus yang bertujuan untuk mengetahui bagaimana pola pengarahan massa untuk memenangkan kolom kosong dengan menggunakan konsep mobilisasi Huntington dan komunikasi massa dari Philip Tichenor. Hasil penelitian menemukan bahwa kemenangan kolom kosong pada pemilihan walikota Makassar dilakukan dengan cara mobilisasi massa yang intens, baik secara langsung maupun tidak langsung. Dengan cara yang tidak langsung mobilisasi ini menggunakan kekuatan media sosial facebook di mana tim sukses dan relawan menformulasi informasi dan pesan untuk menarik perhatian para pemilih ikut berpartisipasi pada pemilihan walikota demi memenangkan kolom kosong.
\end{abstract}

\author{
Kata Kunci: \\ Mobilisasi, Massa, Kolom Kosong, Tim Sukses
}

\begin{abstract}
The study aims to describe the winning of the blank box in Makassar Mayoral Election in 2018. This research used a qualitative method specifically case study to analyze the mass direction pattern in the victory of blank box. By using the Huntington concept of mobilization and mass communication from Philip Tichenor, the study found that the victory of the blank box was caused by means of intense direct and indirect mass mobilization. In an indirect way, this mobilization used the power of social media, Facebook, the success team and volunteers to formulate information and messages that are deliberately carried out for to attract the attention of voters.
\end{abstract}

Keywords:

Mobilization, Mass, Blank Box, Success Team

\section{Pendahuluan}

Perubahan pemilihan umum untuk mewujudkan negara demokrasi telah dilalui dengan melakukan banyak perbaikan, termasuk perbaikan kualitas Pemilihan Kepala Daerah (Pilkada). Dalam kontestasi pemilihan kepala daerah muncul polemik pada Pilkada serentak tanggal 9 Desember 2015, terdapat tiga daerah yang mengusung satu 
calon, yakni Timor Tengah Utara, Blitar, dan Tasikmalaya. Menanggapi permasalahan calon tunggal maka Mahkamah Konstitusi memberikan putusan atas uji materil UU Nomor 8 Tahun 2015 melalui Putusan Nomor 100/PUU-XIII/2015. Dengan putusan ini, Mahkamah Konstitusi membuka jalan bagi beberapa daerah yang hanya memiliki satu pasang calon kepala daerah, sehingga memungkinkan mereka melanjutkan Pilkada tanpa harus menunda ke periode berikutnya. Mahkamah Konstitusi menetapkan pasangan calon melalui pemungutan suara di kolom "Setuju dan Tidak Setuju", dengan tujuan memberikan hak kepada masyarakat untuk memilih. ${ }^{1}$ Setelah itu, muncul Peraturan Komisi Pemilihan Umum (PKPU) Nomor 11 Tahun 2016, di mana pada pasal 11A mengatur surat suara pada pemilihan satu pasangan calon memuat dua kolom yang terdiri atas satu kolom yang memuat foto dan nama pasangan calon dan kolom kosong.

Pada periode Pilkada serentak tahun 2018, terdapat fenomena kolom kosong. Ada 16 calon kepala daerah yang bertarung dengan kolom kosong, salah satunya di Makassar. Pasangan Munafri Arifuddin-Rachmatika Dewi (Appi-Cicu) melawan kolom kosong dan hasil dari Pilkada tersebut KPU menetapkan kolom kosong sebagai pemenangnya.

Kemenangan kolom kosong di Makassar merupakan sejarah baru dalam Pilkada di Indonesia. Kolom kosong memperoleh 300.795 suara, sedangkan calon tunggal memperoleh 264.245 suara. Selisih suara antara kolom kosong dan calon tunggal adalah 36.898 suara. Sementara calon tunggal diusung 10 partai besar di Makassar yaitu, Partai Nasdem, Golkar, PDI-P, PKB, PPP, PBB, PKS, Gerindra, Hanura, dan PKPI.

Upaya rakyat untuk memberi dukungan yang aktif pada kolom kosong menunjukkan beberapa gejala mobilisasi massa dalam pemenangannya, hal ini dilakukan dengan intensitas komunikasi yang tidak hanya satu kali namun juga berulang kali kepada massa. Kenyatannya, dalam memperoleh dukungan untuk kolom kosong, ada individu atau kelompok yang berperan aktif menyampaikan pesan atas pembenaran dari fenomena kolom kosong dalam Pilkada di kota Makassar.

\footnotetext{
${ }^{1}$ Wafia Silvi Dhesinta Rini, "Calon Tunggal Dalam Pemilhan Umum Kepala Daerah Dan Konsep Demokrasi (Analisis Terhadap Pemiihan Kepala Daerah Kabupaten Blitar Tahun 2015)” dalam Jurnal Cita Hukum, Vol. 4, No. 1 (2016), h. 88.
} 
Berdasarkan uraian tersebut, sehingga dalam penelitian ini merumuskan masalah sebagai berikut: bagaimana pola pengarahan massa dalam kemenangan kolom kosong pada Pemilihan Walikota Makassar tahun 2018 ?

\section{Literature Review}

Rujukan literatur berasal dari tema tentang mobilisasi, Kris Nugroho (2011) mengembangkan persepektif tentang mobilisasi dalam electoral yang tidak hanya dikendalikan oleh partai politik, namun juga di luar partai. Melalui penguatan pada jaringan sosial keagamaan dan pengembangan isu gender dapat memobilisasi pemilih perempuan, serta penguatan jaringan etnik dalam memobilisasi persamaan etnik pemilih yang dianggap efektif dalam konstalasi pemilihan. ${ }^{2}$ Selain itu Elwan (2016), menyebutkan model mobilisasi dalam pemilihan kepala desa. Model electoral yang sifatnya langsung dan tidak langsung, bahwa kedua model ini lebih banyak digunakan pada proses kampanye yang menyebarkan isu dan tekanan yang intens dengan tidak mengunakan media sosial. ${ }^{3}$ Sementera itu Permadi (2017), menggambar pemanfaatan jaringan formal dan non formal pada pemilihan gubernur DKI Jakarta. Pada jaringan formal memanfatkan kekuatan elit non partai dan relawan, sementara pada jaringan non formal mengunakan media, baik cetak maupun elektronik. ${ }^{4}$

Penelitian ini menujukkan spesifikasi berbeda dengan penelitian sebelumnya, menekankan pada mobilisasi massa pemilih, melalui sifatnya yang tidak langsung, menggunakan media sosial facebook sebagai upaya penyampaian pesan yang cepat. Mobilisasi yang ada merupakan bentuk kesadaran yang melahirkan partisipasi yang otonom (autonomous participation) dan atas dasar ajakan atau digerakkan orang lain (mobilized participation), namun mobilisasi ini tetap dilakukan dengan metode persuasive, melakukan sosialisasi yang intens dengan menyebarkan dan menarasikan kampanyenya dengan pemaknaan "dizalimi". Efek pengetahun, informasi dan pesan yang telah tersampaikan menyebabkan sebagain besar pemilih tidak lagi

\footnotetext{
${ }^{2}$ Kris Nugroho, "Ikhtiar Teoritik Mengkaji Peran Partai dalam Mobilisasi Poliek Elektoral" dalam Masyarakat, Budaya dan Politik, Vol. 24, No. 3 (2011), h.1-12.

${ }^{3}$ La Ode Muhammad Elwan, "Model dan Dampak Mobilisasi Politik Pemilihan Kepala Desa (Studi Kasus: Desa Bontomatinggi Kabupaten Maros Sulawesi Selatan Tahun 2016)" dalam Journal Publicuho, Vol. 1, No. 4 (2019), h. 1-17

${ }^{4}$ Bagus Permadi, "Kontestasi Pilkada DKI Jakarta Tahun 2017: Studi Tentang Jejaring Mobilisasi Politik Pencalonan Ahok-Djarot" dalam Jurnal Politik Muda, Vol. 6, No.1 (2017), h. 7-13.
} 
mempersoalkan hubungan etnisitas ataupun agama. Penguatan dalam penelitian ini mengambarkan bahwa pemilih aktif berpartisipasi memiliki satu tujuan yang sama untuk memenangkan kolom kosong karena calon tunggal yang ikut pemilihan dianggap tidak layak untuk dipilih.

\section{Memahami Konsep Mobilisasi Politik}

Menurut konsep civil society dan manajemen konfik, mobilisasi merupakan model persaingan dan konflik yang mewarnai negara-rakyat. Mobilisasi merupakan salah satu varian aksi kolektif dalam proses persaingan atau konflik antar kelompok yang berkaitan dengan kekuasaan, kepentingan, dan tujuan yang berbeda. Mobilisasi menekankan tindakan kolektif semua pihak dalam hal kepentingan kolektif, tingkat organisasi, jumlah sumber daya yang berada di bawah kendali kolektif, serta peluang dan ancaman yang dihadapi dalam persaingan atau konflik. ${ }^{5}$

Dalam demokrasi, politik mobilisasi massa nyaris tidak mungkin dihindari. Sebab demokrasi itu sendiri juga lahir dari kesadaran publik atau massa akan haknya sebagai pemilik tertinggi kekuasaan. Samuel P. Huntington menjelaskan bahwa partisipasi politik rakyat didasarkan pada dua kecenderungan, yaitu berdasarkan kesadaran kemudian menciptakan partisipasi yang mandiri (autonomous participation) dan berdasarkan ajakan atau mobilisasi untuk berpartisipasi (mobilized participation).

Samuel P. Huntington menjelaskan salah satu cara yang digunakan dalam memobilisasi adalah dengan melalui pendekatan persuasif, ialah mobilisasi yang dilakukan dengan bujukan secara halus dan ajakan kepada massa untuk turut berpartisipasi meraih kepentingan pihak yang memobilisir (mobilizer). Langkahlangkah persuasif tersebut dimulai dari tahapan awal ketika mobilizer menjalin kontak hingga pada saat mobilizer menunjukkan tendensi serta kepentingan politiknya kepada massa.

Mobilisasi menurut Stefano ada dua, yaitu mobilisasi langsung dan mobilisasi tidak langsung. Mobilisasi langsung adalah kegiatan mobilisasi berupa pengerahan pemilih untuk melakukan tindakan politik sesuai dengan keinginan partai. Mobilisasi tidak langsung adalah kegiatan mobilisasi yang dilakukan dalam bentuk mempengaruhi

${ }^{5}$ Hilmy Mochtar, Demokrasi Dan Politk Lakol Di Kota Santri (Malang: UB Press, 2011), h 171. 
pemikiran atau pendapat pemilih, sehingga pemilih akan mengungkapkan pemahamannya dalam bentuk keputusan politik pemilih. ${ }^{6}$

Kegiatan mobilisasi politik yang digunakan untuk keperluan pemilu (electoral) tidak hanya dilakukan oleh partai politik, tetapi dapat juga dilakukan melalui instrumen mobilisasi politik non partai. Melalui sejumlah literature review dan penelitian oleh para sarjana politik, terlihat bahwa alat mobilisasi politik non partai digunakan untuk mendukung kegiatan mobilisasi politik untuk kepentingan electoral. Kapasitas kelembagaan partai politik untuk memobilisasi massa sangat rendah, dan calon aktor secara pragmatis memilih menggunakan alat mobilisasi politik non partai, dan alat mobilisasi politik non partai dinilai lebih efektif daripada alat mobilisasi partai. ${ }^{7}$

Salah satu jaringan politik yang tercipta dalam kampanye calon kepala daerah yakni kelompok kepentingan non-partai yang ikut dan jadi aktor politik dalam mendukung pasangan calon. Kelompok non-partai ini umumnya berbentuk gabungan anak muda yang mulai memahami politik serta memutuskan untuk mendukung salah satu pasangan calon kelompok ini terpisah dengan kelompok partisan dari partai politik. Pada kampanye calon kepala daerah, kelompok non-partai ini bisa dengan gampang dimobilisasi serta memoblisasi kelompok lain dalam kaitannya dukungan pencalonan. Mobilisasi pencalonan merupakan usaha yang bertujuan untuk menggerakkan masyarakat sebagai pemilik hak suara yang legal dalam sebuah pemilihan umum. Mobilisasi pencalonan ialah kegiatan penting dalam kampanye politik, dalam meningkatkan dukungan pada pasangan calon peran mobilisasi pencalonan dapat meningkatkan suara pemilih. ${ }^{8}$

\section{Teori Komunikasi Massa}

Dalam literature, komunikasi massa adalah suatu proses di mana seseorang atau sekelompok orang atau organisasi besar menyusun suatu pesan, kemudian mengirimkannya ke berbagai khalayak yang homogen dan heterogen melalui berbagai

${ }^{6}$ Asmoro Pujo, "Sepak Bola dan Politik: Mobilisas Massa Suporter PSIS Semarang Oleh Alamsyah Satyanegara Sukawjaya Untuk Pemenangan Pemilu Legislatif Tahun 2014". Skripsi. (Semarang: Universitas Wahid Hasyim Semarang, 2018), h.10.

${ }^{7}$ Kris Nugroho, Loc. Cit.

${ }^{8}$ Cindy Indira Firdausi, "Jaringan Politik Dalam Pilwali Surabaya Tahun 2015 Studi Peran Pemuda PIS Dalam Mendukung Pencalonan Risma - Whisnu” dalam Jurnal Politik Muda, Vol 6, No 1 (2017), h. 27-33. 
media. Dalam beberapa perkembangan, seiring dengan perkembangan teknologi informasi dan komunikasi, kemunculan media komunikasi modern cenderung mengaburkan batasan antara komunikasi interpersonal atau komunikasi interpersonal tradisional dengan komunikasi massa.

Komunikasi massa merupakan salah satu bentuk komunikasi baru yang dikaji dalam tiga paradigma, yaitu: paradigma pertama adalah paradigma kekuatan efek media yang melihat kuatnya pengaruh media terhadap khalayak massa; Paradigma kedua, adalah paradigma efek terbatas atau efek minimalis media terhadap khalayak massa; Paradigma ketiga, paradigmaa efak kumulatif media terhadap khalayak massa. Sementara itu dalam perkembangan teori komunikasi massa, terdapat teori yang disebut dengan kesenjangan pengetahuan. Teori ini diperkenalkan oleh Phiip Tichenor, George Donohue dan Clarice Olien, disebutkannya bahwa bertambahnya jumlah informasi mengenai suatu topik mengakibatkan bertambahnya pula kesenjangan pengetahuan antara mereka yang mengetahui lebih banyak dan mereka yang mengetahui lebih sedikit.

Teori ini juga menjeleskan bahwa pengetahuan dapat membantu menjelaskan berbagai permalasahan yang ditimbulkan dari opini publik. Kesenjangan pengetahuan dapat menghasikan bertambahnya kesenjangan antara orang-orang yang memiliki status sosio-ekonomi yang rendah dan orang-orang yang memliki sosio-ekonomi yang tinggi. Terdapat lima alasan untuk menjustifikasi terjadinya kesenjangan pengetahun dan informasi dari orang orang yang memliki sosio-ekonomi tinggi, yaitu: (1) Memiliki keterampilan komunikasi, pendidikan, kemampuan membaca, kemampuan mengingat informasi yang lebih baik. (2) Dapat menyimpan informasi secara lebih mudah atau mengingat topik berdasarkan latar belakang pengatahuan. (3) Memilki konteks sosial yang lebih tinggi (4) Lebih baik dalam melakukan terpaan selektif, penerimaan dan terensi. (5) Mudah menjangkau media massa.

Dari uraian tersebut, dipahami bahwa komunikasi massa merupakan proses dimana organisasi membuat dan menyebarkan pesan pada khalayak, dimana organisasi ini menyebarkan informasi yang kan mempengaruhi dan mencerminkan kebudayaan suatu masyarakat, lalu informasi ini akan mereka hadirkan serentak pada khalayak yang beragam yang penerimaannya dapat menimbulkan kesejangan dalam pengetahuan dan informasinya. 


\section{Metode Penelitian}

Metode penelitian yang digunakan dalam tulisan ini adalah adalah kualitatif, yang menghasilkan data deskriptif: tulisan dan perilaku yang diamati dari orang-orang (subjek) itu sendiri. ${ }^{9}$ Penelitian kualitatif mencoba untuk memahami, mendalami, dan menerobos masuk di dalamnya terhadap suatu gejala-gejala. Sehingga dicapai suatu simpulan yang obyektif dan alamiah sesuai dengan gejala-geiala pada konteks tertentu. $^{10}$

Jenis penelitian ini merupakan studi kasus yang bermaksud mendeskripsikan hasil penelitian serta berupaya mendapatkan gambaran menyeluruh mengenai suatu kondisi. Pilihan terhadap metodologi ini adalah karena fenomena yang diteliti ialah suatu kasus yang memerlukan pengkajan deskriptif yang mendalam, yaitu untuk mengetahui pola pengarahan massa yang terjadi di pemiihan walikota di Makassar tahun 2018 mengenai kemenangan kolam kosong.

Studi kasus penelitian bertujuan untuk menguji pertanyaan dan masalah penelitian, yang tidak dapat dipisahkan antara fenomena dan konteks di mana fenomena tersebut terjadi. ${ }^{11}$ Studi kasus sebagai suatu strategi penelitian digunakan dalam penelitian ini dengan beberapa alasan. Pertama, berkatan dengan pertanyaan penelitian. Yin menjelaskan bahwa studi kasus dapat digunakan untuk menjawab pertanyaan penelitian berupa bagaimana (how) dan mengapa (why). la berargumen bahwa kedua pertanyaan tersebut mengindikasikan perlunya eksplorasi terhadap permasalahan yang ingin dijawab melalui penelitian. Kedua adalah berkaitan dengan kontrol terhadap perilaku yang diteliti. Studi kasus umum digunakan ketika perilaku subyek yang diteliti tidak dapat dimanipulasi. Alasan ketiga berkaitan dengan fokus terhadap kontemporeritas. Diuraikan oleh Yin bahwa studi kasus memfokuskan diri untuk meneliti fenomena-fenomena yang cukup kontemporer. ${ }^{12}$

22.

${ }^{9}$ Arief Furchan, Pengantar Metode Penelition Kualitatif (Surabaya: Usaha Nasional, 1992), h.21-

${ }^{10}$ Suyitno, Metode Peneitian Kualitatif Konsep, Prinsip don Operasionainya (Tulungagung: Akademia Pustaka, 2018), h. 6.

${ }^{11}$ Unika Prihatsanti, Suryanto \& Wiwin Hendriani, "Menggunakan studi kasus sebagai metode ilmiah dalam Psikologi” dalam Buletin Psikologi, Vol. 26, No. 2 (2018), h. 128.

${ }^{12}$ Teddi Prasetya Yuliawan \& Fathul Himam, "The Grasshopper Phenomenon: Studi Kasus Terhadap Profesional yang Sering Berpindah-pindah Pekerjaan” dalam Jurnal Psikologi, Vol 34, No. 1 (2007), h. 81. 
Beberapa kasus yang amat jarang ditemui dan karenanya belum banyak penelitian yang berusaha mengungkapnya menjadi hal yang mendasari penelitian menggunakan studi kasus. Hal yang terakhir tersebut peneliti jadikan alasan utama penggunaan studi kasus dalam penelitian ini. Hal ini dikarenakan berbagai penelitian yang ada baru sampai menjawab mengapa kolom kosong bisa terjadi di dalam Pilkada, belum menjawab faktor-faktor di dalam kemenangan kolom kosong terutama mengenai pola pengarahan massa di dalam fenemona kolom kosong.

Lokasi penelitian yaitu di Kota Makassar, alasan dipilihnya lokasi ini mengingat fenomena kemenangan kolom kosong terjadi pada Pilkada di Makassar, terdapat 15 kecamatan yang ada di Makassar, namun hanya dua yang memenangkan calon tunggal sementara tiga belas kecamatan lainnya memenangkan kolom kosong.

\section{Potret Pemilihan Walikota di Makassar Tahun 2018}

Pemilu yang dilaksanakan di Kota Makassar merupakan kontestasi untuk pemilihan kepala daerah, yaitu walikota dan wakil walikota. Kota Makassar merupakan ibukota Provinsi Sulawesi Selatan yang memiliki masyarakat heterogen dan untuk kesekian kalinya melaksanakan pesta demokrasi lima tahunan. Untuk periode 20182023, Pilkada di Kota Makassar telah dilaksanakan pada tanggal 27 Juni 2018 dan pesertanya hanya satu pasang calon yang melawan kolom kosong.

Hasil kontestasi antara pasangan Munafri Arifuddin-Rachmatika Dewi melawan kolom kosong dimenangkan oleh kolom kosong. Adapun dari 15 kecamatan yang ada, 13 kecamatan dimenangkan oleh kolom kosong, sedangkan 2 kecamatan yang lain dimenangkan pasangan Munafri Arifuddin-Rachmatika Dewi. Berikut jumlah peroleh suara pada pemilukada walikota Makassar tahun 2018

Tabel 1.

Jumlah Perolehan Suara 15 Kecamatan di Kota Makassar

\begin{tabular}{|l|l|l|l|l|}
\hline $\begin{array}{c}\text { Nama } \\
\text { Kecamatan }\end{array}$ & Hak Pilih & Appi-Cicu & $\begin{array}{l}\text { Kolom } \\
\text { Kosong }\end{array}$ & $\begin{array}{l}\text { Suara } \\
\text { sah }\end{array}$ \\
\hline Mamajang & 25.042 & 10.886 & 13.407 & 24.293 \\
\hline Manggala & 93.929 & 30.384 & 27.631 & 58.015 \\
\hline
\end{tabular}




\begin{tabular}{|l|l|l|l|l|}
\hline Tamalate & 146.555 & 33.817 & 33.541 & 67.358 \\
\hline Tallo & 57.979 & 26.297 & 29.122 & 55.419 \\
\hline Mariso & 25.197 & 11.566 & 12.845 & 24.411 \\
\hline Biringkanaya & 77.862 & 36.092 & 39.320 & 75.415 \\
\hline $\begin{array}{l}\text { Kep. } \\
\text { Sangkarrang }\end{array}$ & 7.242 & 3.261 & 3.645 & 6.906 \\
\hline Panakkukang & 58.229 & 25.069 & 31.108 & 56.177 \\
\hline Rappocini & 64.041 & 29.844 & 32.460 & 62.304 \\
\hline Tamalanrea & 39.214 & 16.912 & 21.138 & 38.050 \\
\hline Ujung Tanah & 16.249 & 7.362 & 8.317 & 15.679 \\
\hline Wajo & 13.010 & 4.695 & 7.954 & 12.649 \\
\hline Bontoala & 23.362 & 10.584 & 11.907 & 22.491 \\
\hline Makassar & 35.854 & 13.654 & 21.081 & 34.735 \\
\hline $\begin{array}{l}\text { Ujung } \\
\text { Pandang }\end{array}$ & 11.440 & 3.822 & 7.319 & 11.114 \\
\hline
\end{tabular}

Sumber: Data KPU Makassar tahun 2018

Pasangan Munafri Arifuddin-Rachmatika Dewi awalnya telah mengunggat calon pasangan lain yakni Danny Pomanto-Indira Mulyasari (DIA-mi). Sebagai incumbent, Danny Pomanto-Indira Mulyasari digugat pencalonannya ke Pengadilan Tinggi Tata Usaha Negara Makassar terkait program pemerintahan Danny Pomanto yang membagi telepon seluler kepada rukun tetangga dan rukun warga. Perkara ini menggugurkan pasangan Danny Pomanto-Indira Mulyasari sebagai kontestan dan pada akhirnya KPU menetapkan Pilkada Makssar 2018 hanya diikuti oleh satu pasang calon saja, yakni Munafri Arifuddin-Rachmatika Dewi.

Pasangan Munafri Arifuddin-Rachmatika Dewi telah mendapat dukungan dari 10 partai politik, yaitu Partai Nasdem, Golkar, PDI-P, Gerindra, Hanura, PKB, PPP, PBB, PKS, dan PKPI, namun pasangan ini malah tidak mendapat dukungan yang layak dari masyarakat di Kota Makassar. Kemenangan kolom kosong merupakan tamparan keras untuk partai politik karena dinilai gagal dalam melakukan perannya sebagai pendukung pasangan calon tunggal, sebaliknya tim pemenangan Danny Pomanto-Indira 
Mulyasari sangat aktif dan lebih banyak berkampanye di masyarakat untuk memenangkan kolom kosong.

\section{Pola Pengarahan Massa Pada Pemilihan Walikota Makassar}

Masyarakat Makassar dalam pemilihan walikota telah menunjukkan partisipasinya secara aktif dengan ikut memilih dan memenangkan kolom kosong. Dukungan penuh masyarakat terhadap pelaksanaan pemilihan walikota mencerminkan dukungan aktif pada peraturan KPU dan kebijakan negara. Walaupun dalam kontestasi ini, terdapat gejala mobilisasi politik yang mewarnainya yang dilakukan tidak hanya oleh individu namun juga beberapa kelompok masyarakat yang berperan aktif agar masyarakat berpartisipasi secara politik dan mempengaruhi pilihan mereka.

Sebelum pasangan Danny Pomanto-Indira Mulyasari didiskualifikasi dari kontestasi pemilukada, Panglima Markas Perlawanan Rakyat (Menara) Tim Pemenangan Danny Pomanto-Indira Mulyasari telah mensosialisasi kolom kosong lebih dulu. Sosialisasi pertama tersebut terbatas pada simpatisan dan relawan DIA-mi di Sekretariat DPC Partai Demokrat Makassar. Ketua DPC Partai Demokrat Makassar menjelaskan dalam sosialisasinya bahwa memilih kolom kosong sama saja dengan memilih DIA-mi.

Untuk memperoleh dukungan yang besar, salah satu upaya yang bisa dilakukan adalah dengan sosialisasi. Mendekati masyarakat atau kelompok-kelompok yang ada di dalam masyarakat baik itu formal maupun non-formal untuk mempermudah mengumpulkan suara. Sosialiasi untuk memenangkan kolom kosong ini banyak dilakukan sebagian Ketua Rukun Tetangga dan Ketua Rukun Warga (RT/RW) pada sejumlah kecamatan di Makassar. Misalnya, warga RW 01 RT 04 di Kelurahan Sambung Jawa, Kecamatan Mamajang bersama salah satu tokoh perempuan di Kelurahan Sambung Jawa melakukan sosialisasi kolom kosong dengan menebar selebaran untuk mengajak memilih kolom kosong. Pengarahan massa juga terjadi di Kelurahan Pa'baeng-baeng, Kecamatan Tamalate, di mana Ketua RW 06 menegaskan adanya kesepakatan bersama untuk tidak memilih pasangan Munafri ArifuddinRachmatika Dewi, dan berjanji memenangkan kolom kosong.

Ketua RW/RT dan warga Kecamatan Manggala dengan tegas menunjukkan dukungannya untuk menenangkan kolom kosong. Seperti yang dilakukan jaringan 
Bombardir dan Komunitas Pro Danny Pomanto beserta warga dari beberapa kelurahan di Kecamatan Manggala, di salah satu warung kopi di Kecamatan Manggala bersama Ketua LPM Kelurahan Bangkala mengadakan rapat untuk membahas sosialisasi kolom kosong untuk memenangkan kolom kosong. Dalam sosialisasinya, ada beberapa hal yang disampaikan, salah satunya menegaskan bahwa jika kolom kosong menang maka Danny-Indira dapat bertarung di Pilkada berikutnya.

Sejumlah komunitas dan kelompok pendukung kolom kosong muncul ketika pasangan Danny Pomanto-Indira Mulyasari didiskualifikasi, sekitar 50 orang massa pendukung setia DIA-mi yang berunjuk rasa di bawah fly over menyerukan kepada warga Makassar untuk bergotong royong memenangkan kolom kosong sekaligus meluncurkan kelompok mereka yang diberi label Relawan Kolom Kosong (Rewako). Mereka berasal dari sejumlah kelurahan dan kecamatan di Makassar, dalam aksi tersebut Rewako membagikan selebaran kepada pengguna jalan yang memuat seruan "pilih kolom kosong dan mengapa harus kolom kosong".

Komunitas Laskar Jeneponto, Komunitas Pemuda Utara, Komunitas Turikale, Laskar Karuwisi, Komunitas Massenrengpulu, ormas Pemuda Pancasila, Laskar Merah Putih, dan lain sebagainya antusias mendukung kolom kosong dengan mengkampanyekan kolom kosong. Seperti yang dilakukan Laskar Jeneponto, di mana mencetak baliho mengajak warga untuk mencoblos kolom kosong. Selain baliho, muncul pernak-pernik dan atribut kolom kosong seperti adanya baju yang dibagibagikan kepada warga. Salah satu warga di Kelurahan Sinrijalla yang mencetak baju "kotak kosong pilihanku" yang kemudian dibagi-bagikan kepada warga, menjelaskan bahwa arahan untuk mendukung kolom kosong agar Danny Pomanto bisa ikut Pilkada selanjutnya dan dapat memimpin Makassar kembali.

\section{Gambar 1.}

Salah Satu Baliho Milik Laskar Jeneponto

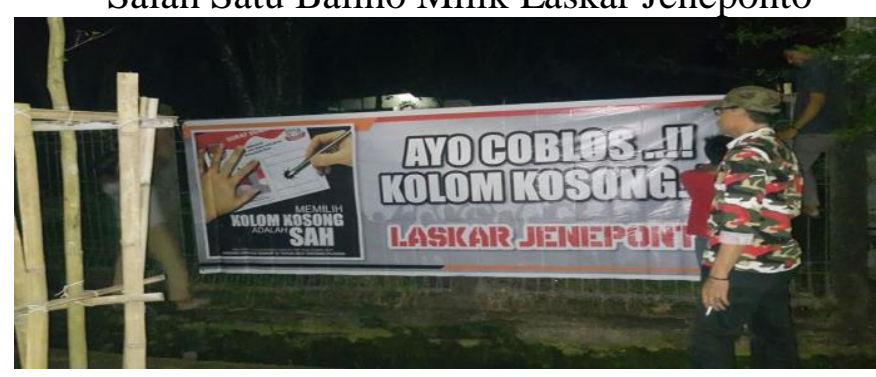

Sumber: Arsip Pribadi. 


\section{Penguatan Pengarahan Massa Tidak Langsung Melalui Media Sosial Facebook}

Bentuk pola pengarahan tidak langsung biasanya menggunakan media untuk mempengaruhi pemilih. Peran media dalam pengarahan massa sangatlah penting. Hampir tidak ada satupun calon pasangan atau tim sukses yang tidak menggunakan media sosial dalam sosialisasi dan kampanye. Media dianggap sebagai sarana yang efektif dan masif dalam menginformasikan dan memperkenalkan calon pasangan maupun partai politik berikut program-programnya. Media bisa mengonstruksi cara pandang khalayak terkait peristiwa-peristiwa seputar pemilu. Dalam melakukan peran tersebut, media bisa berada pada posisi membela kemapanan, mempertahankan rezim atau menumbuhkan perubahan melalui pemikiran-pemikiran kritis.

Media sosial ini dimanfaatkan oleh para pendukung kolom kosong. Salah satu grup di media sosial Facebook dengan nama Gerakan Kotak Kosong Makassar (GKKM) beranggotakan 1.013 ini ramai dengan kegiatan-kegiatan meneriakkan dukungan kolom kosong. Mulai dari foto-foto spanduk kolom kosong yang terpasang di lorong-lorong setiap kecamatan, pertemuan membahas kolom kosong, baju kolom kosong, dan poster-poster untuk mendukung kolom kosong. Grup dengan jumlah admin sebanyak 9 orang, penulis tidak bisa menghubungi pendiri grup dikarenakan akun-akun pendiri grup sudah tidak digunakan.

Salah satu anggota dari Crisis Center Kolom Kosong yang bekerja mengawasi kegiatan mengenai kolom kosong di Facebook mengatakan :

"Saya bekerja di media sosial, mensosialisasikan kolom kosong, melihat sosialisasi teman-teman dan mengamati laporan seperti kecurangan yang terjadi di TPS. Untuk bukti, sudah tidak ada. Saya sudah hapus setelah Kolom Kosong dinyatakan menang. Saya kira banyak memang yang seperti itu. Banyak yang membuat akun fiktif atau buat akun hanya untuk kegiatan pemilu kemarin." 13

Dari hasil wawancara tersebut banyak akun yang sengaja dibuat untuk mensosialisasikan kolom kosong, dan setelah kolom kosong menang akun tersebut sudah tidak diaktifkan lagi. Sementara itu hal yang sama juga dilakukan oleh grup GKKM, salah satu anggota grup yang jejak postingan masih ada, menyebutkan:

\footnotetext{
${ }^{13}$ Reza, Anggota Crisis Center Kolom Kosong, wawancara,15 Mei 2019.
} 
"Saya ini sudah ikut sama Pak Danny sejak awal. Kalau dibilang kecewa memang ada tapi bukan itu intinya. Kasarnya, ada oknum lembaga yang memihak salah satu paslon (pasangan calon), oknum lembaga ini yang harusnya bekerja untuk mensosialisasikan kolom kosong tapi tidak dilakukan jadi kami sebagai masyarakat merasa perlu turun sosialisasikan itu. Sejak awal Pak Danny memang sudah berat, maju sebagai calon independen dan diserang dimanamana. Pemilih di Makassar sudah pintar, melihat adanya hal-hal di luar kebiasaan seperti melihat ketidakadilan dan kedzholiman. Yang saya kagum itu, Pak Danny tidak menunjukkan dirinya di dzholimi, tetap sabar. Kesabarannya itu membawa kemenangan untuk kolom kosong menang. Saya aktif sosialisasikan kolom kosong di Kelurahan, di Kecamatan Bontoala, dan media sosial. Paling sering di media sosial karena disana kita bebas mengutarakan pendapat atau bersuara tanpa banyak batasan. Walau saya juga berkomunikasi dengan anggota tim sukses Pak Danny dan pernah ikut sosialisasi dari tim sukses tapi Pak Danny tidak pernah turun langsung. Sabar. Saya juga jadi semakin tergerak untuk melakukan sosialisasi. Melihat calon lain tidak memiliki kapabilitas artinya masih ada yang lebih mampu memimpin masyarakat jadi daripada kita dipimpin oleh calon yang belum jelas, kita menangkan saja kolam kosong." 14

Ungkapan informan diatas tidak jauh berbeda dari penjelasan GKKM yang dapat dilihat ketika membuka grup GKKM di Facebook.

Gambar 2.

Tangkapan Layar Facebook

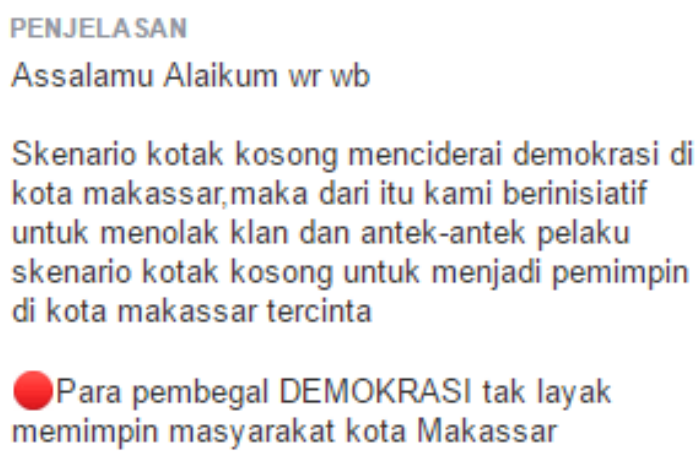

Sumber: Grup Gerakan Kolom Kosong Makassar di Facebook

Anggota grup memiliki satu pemikiran yaitu merasa bahwa ada pihak-pihak mencoba menciderai demokrasi di Makassar. Isi dari kampanye dan sosialisasi yang dilakukan anggota GKKM berbunyi tidak jauh berbeda dari penjelasan grup GKKM itu sendiri. Dari hasil observasi yang penulis lakukan, admin dari grup GKKM ini adalah

\footnotetext{
${ }^{14}$ Almalik, Anggota Grup GKKM, wawancara, 2 Mei 2019.
} 
orang-orang yang mendukung DIA-mi sehingga tidak heran jika penjelasan grup GKKM adalah bentuk opini publik untuk memperburuk pasangan calon tunggal.

Gambar 3.

Tangkapan Layar Facebook

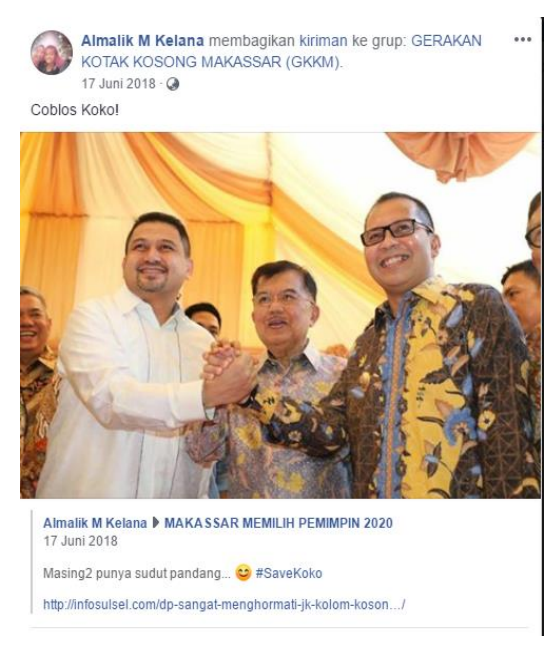

Sumber: postingan Almalik di Facebook

Dari postingan 17 Juni 2018, informan membagikan tautan berita dengan judul '’DP Sangat Menghormati JK, KOKO Diambang Kemenangan Besar'’. Di dalam tautan berita tersebut dibahas tentang Jusuf Kalla yang mencoba mendamaikan Munafri Arifudddin dan Moh. Ramdhan Pomanto hingga bagaimana foto tersebut menyudutkan Moh. Ramdhan Pomanto yang mengatakan bahwa Pilwali Makassar 2018 telah game over - yang segera ditepis oleh tim Danny Pomanto-Indira Mulyasari. Tim pasangan Danny Pomanto-Indira Mulyasari dalam tautan berita tersebut mengungkap bagaimana sifat tawadhu seorang Danny Pomanto meski difitnah, dibully pada pemilihan walikota Makassar namun tetap tegar dan menghargai Jusuf Kalla sebagai orang tua. Tautan tersebut disebar dengan keseluruh grup GKKM, sehingga penguatan sosialisasinya oleh tim sukses Danny Pomanto-Indira Mulyasari mendapat banyak simpati dari pemilih. 
Gambar 4.

Tangkapan Layar Facebook

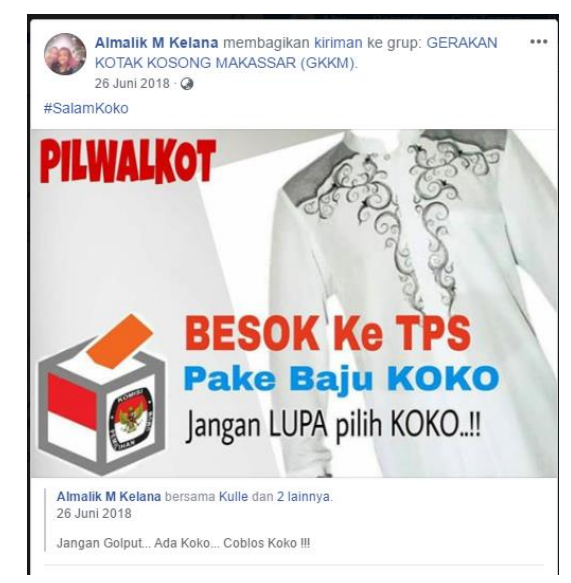

Sumber: postingan Almalik di Facebook

Dari postingan 26 Juni 2018, informan juga telah membagikan sebuah tautan mengajak anggota grup GKKM untuk datang memilih kolom kosong ke Tempat Pemungutan Suara (TPS) dan meminta agar tidak Golput (Golongan Putih). Dari hasil observasi penulis lewat postingan informan di Facebook menunjukkan bahwa meskipun secara struktur tidak masuk ke dalam tim sukses Danny Pomanto-Indira Mulyasari, informan ini aktif dalam mensosialisasikan kolom kosong. Struktur sosialisasi yang dilakukan informan di media sosial tidak jauh beda dari tim sukses yang melakukan pengarahan secara langsung. Informan telah menggunakan struktur yang sama yaitu mencari simpati masyarakat lewat opini publik yang sejak awal dibangun oleh tim sukses Danny Pomanto-Indira Mulyasari sejak didiskualifikasi.

Sementara itu, informan lain sebagai anggota dari Relawan Kolom Kosong (Rewako) melakukan sosialiasi di media sosial lebih kepada bukti-bukti kerja yang dilakukan oleh tim Rewako dilapangan, disebutkannya:

"Saya lebih aktif di media sosial tapi saya juga ikut membagikan selebaran di jalan cuma lebih vokal di medsos karena lebih mudah terhubung dengan masyarakat lain dengan mengirimkan tautan-tautan di beberapa grup." 15

Pernyataan dari informan tersebut sejalan dengan postingan-postingannya yang ada di media sosial Facebook.

\footnotetext{
${ }^{15}$ Igaruddin, Anggota dari Relawan Kolom Kosong (REWAKO), wawancara, 22 Juni 2019.
} 
Gambar 5.

Tangkapan Layar Facebook

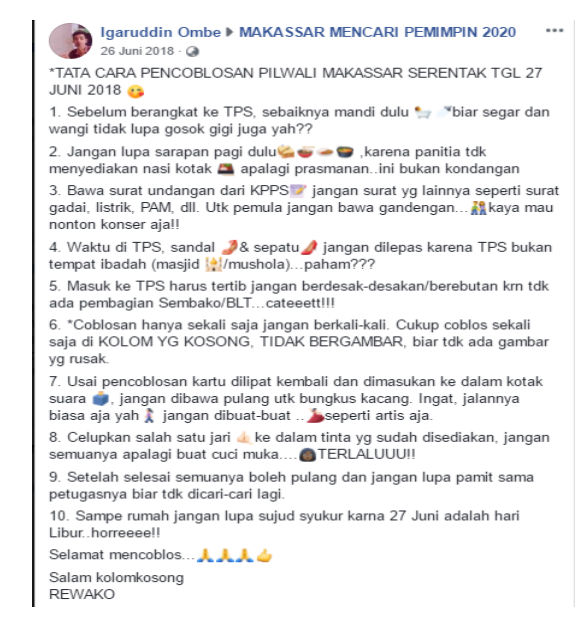

Sumber: postingan Igaruddin di Facebook

Sejalan dengan pernyataan yang dikemukakan oleh koodinator Rewako, Anshar Manrulu bahwa Rewako bergerak atas dasar gerakan hati nurani dan melawan oligarki politik. Postingan yang ada pada tanggal 26 Juni 2018 berisi sebuah ajakan untuk datang memilih kolom kosong dibungkus dengan kalimat sederhana dan ringan. Hasil observasi dari postingan disebutkan tidak ada postingan yang menyinggung pasangan calon tunggal, hanya mencari simpati atas didiskualifikasinya pasangan Danny Pomanto-Indira Mulyasari.

Dari dua hasil wawancara dari anggota grup yang berbeda, dapat disimpulkan bahwa ada dua pola pengarahan massa yaang terjadi di media sosial Facebook. Pertama, dengan melakukan sosialisasi lewat opini publik untuk mendapatkan simpati. Kedua, dengan melakukan sosialisasi dengan mengedukasi atau memberikan pendidikan politik dasar. Dari dua pola mobilisasi yang dilakukan baik dari tim sukses DIA-mi dan pendukung kolom kosong, pandangan dari informan yang merupakan dosen di salah satu perguruan tinggi negeri, menyebutkan:

"Fenomena kemenangan kolom kosong di luar kebiasaan demokrasi kita yang terjadi di Indonesia. Memang pada saat itu banyak lembaga survei memang awalnya mengunggulkan Appi-Cicu karena didukung oleh koalisi partai yang besar akan tetapi kita lihat bahwa ternyata diakhir cerita yang menang adalah kotak kosong. Ini di luar dari kebiasaan demokrasi kita, kita melihat bahwa bisa saja dengan banyaknya koalisi yang tergabung dalam koalisi Appi-Cicu tidak memungkiri bahwa jelaslah dia akan memenangkan pertandingan tapi lain cerita 
boleh saja ada syarat atau ada ketentuan koalisi partai tidak bekerja dan kemudian isu dan opini yang dibangun oleh timnya pak danny pada publik tibatiba membuat keinginan masyarakat makassar yang masuk di dalam opini seolah-olah proses pemilu sehingga memunculkan calon tunggal dan kotak kosong sesuatu yang tidak benar, menyalahi aturan, kemudian pak danny memposisikan dirinya sebagai orang yang dizholimi. Sehingga masyarakat makasssar ini merasa ada permainan yang tidak wajar. Seperti itulah demokrasi kita, ketidakwajaran itu selalu dibungkus dengan opini dan isu, tergantung siapa yang memainkan opini itu. Apakah kemudian massa bisa terpengaruh, tapi akhirnya kan kemudian massa boleh dianggap terpengaruh boleh dianggap terjebak dengan permainan isu politik, ada pendzholim, ada dzholimi, ada yang merasa dizholimi. Kemudian masyarakat merasa perlu membantu yang dizholimi ini, disini adalah Pak Danny Pomanto, muncullah kemudian komunitas-komunitas di luar dari ikatan tim inti pak danny seperti misalnya ikatan silent mayority. Kita-kita yang tidak pernah melihat mereka berkomentar tapi membuat sebuah gerakan yang luarbiasa sampai hari mencoblosan sehingga membuat kita akhirnya terpengaruhlah. Menurut saya, mampu mempengaruh opini masyarakat bergerak melawan koalisi besar."16

Pernyataan tersebut menyimpulkan bahwa dalam kemenangan kolom kosong pada pemilihan walikota Makassar tahun 2018, terdapat pihak-pihak yang mengarahkan dan diarahkan, sehingga sebagian besar dari para pemilih di kota Makassar memutuskan ikut berpartisipasi dalam pemilihan walikota untuk memilih kolom kosong.

Atas fenomena tersebut, salah satu sosiolog politik dari universitas negeri di kota Makassar berpandangan;

"Kemunculan kelompok-kelompok kolom kosong dan kemenangan kolom kosong semuanya sudah di desain sejak awal. Ada banyak kepentingan di dalam kolom kosong itu, banyak figur yang bermain tapi tidak memunculkan diri sebagai pendukung kolom kosong pada saat kemarin. Buktinya sekarang ada banyak nama yang muncul dipermukaan untuk pilwalkot mendatang. Tentu kemenangan kolom kosong menjadi tamparan bagi fraksi-fraksi atau orangorang yang berkeinginan maju duduk di kursi pemerintahakan karena calon tunggal kemarin yang dianggap sudah memiliki segalanya justru gagal."17

Atas uraian tersebut di atas, dapat dianalisis bahwa; pertama, pemilihan walikota Makassar tahun 2018 telah menyisakan banyak persoalan yang mencederai demokrasi. KPU cenderung tidak obyektif dalam menentukan bakal calon walikota Makassar. Kedua, pemilihan walikota Makassar tahun 2018 membangun bentuk mobilisasi yang sangat kuat kepada masyarakat pemilih, tidak hanya pada mobilisasi

${ }^{16}$ Fajar, Dosen UIN Alauddin Makassar, wawancara, 28 Juni 2019.

${ }^{17}$ Muhammad Saiful, Sosiolog Politik UNM, wawancara, 28 Juni 2019. 
langsung oleh tim sukses ataupun kelompok relawan, namun juga dilakukan dengan mobilisasi tidak langsung, yaitu dengan menggunakan kekuatan media sosial sebagai bagian menyampaikan pesan yang sifatnya cepat.

Ketiga, mobilisasi dalam pemilihan walikota Makasaar menunjukkan model yang dikembangkan dari pemikiran Huntington. Disebutkannya bahwa besaran partisipasi seseorang ataupun kelompok didasarkan pada atas dua kecenderungan, yaitu atas dasar kesadaran yang kemudian melahirkan partisipasi yang otonom (autonomous participation) dan atas dasar ajakan atau digerakkan orang lain (mobilized participation). Pemilihan walikota Makassar jelas menunjukkan bahwa masyarakat pemilih lebih banyak teradopsi dari pengarahan yang dilakukan oleh tim sukses, pemilih kecendrungannya lebih banyak dimobilisasi dengan berbagai cara untuk memenangkan kolom kosong.

Keempat, mobilisasi pemilih pada pemilihan walikota Makassar dilakukan dengan metode persuasive, yang oleh Huntington itu dibenarkan dalam demokrasi. Model ini tergambar dengan jelas saat tim sukses pasangan Danny Pamanto-Indira Mulyasari melakukan sosialisasi yang intens dengan menyebarkan pesan pada khalayak untuk menarik simpatik dan empatik guna mendapat suara pemilih di Makassar. Tim sukses lebih banyak menarasikan kampanyenya dengan pemaknaan "dizalimi”.

Kelima, pemilihan walikota Makssar tahun 2018 menggunakan media sosial sebagai salah satu alat mobilisasi, efek media telah membangun komunikasi massa yang menyebar dari pesan yang dibangun oleh tim sukses dan beberapa relawan pasangan Danny Pamanto-Indira Mulyasari melalui Facebook dan jaringan media sosial lainnya. Ini menunjukkan bahwa media memberikan efek yang sangat kuat ketika pesan yang disampaikan tersebut berdampak baik langsung maupun tidak langsung kepada penerima pesannya. Kuatnya efek media ini dalam pemilihan walikota Makassar tahun 2018 telah memenangkan kolom kosong yang dipilih oleh sebagian besar masyarakat di Kota Makassar.

Keenam, pemilihan walikota Makassar juga menggambarkan situasi komunikasi yang dikembangkan dari teori komunikasi massa tentang kesenjangan pengetahuan oleh pemikiran Philip Tichenor, bahwa sebagian besar masyarakat pemilih terdistorsi pengetahuan dan informasinya terkait calon yang ikut dalam kontestasi tersebut. Ada masyarakat pemilih yang memiliki keterampilan dan pendidikan yang mampu 
memahami informasi dan pesan yang disampaikan oleh tim sukses pasangan Danny Pamanto-Indira Mulyasari, namun ada juga masyarakat pemilih yang kurang mampu memahami informasi dan pesan tersebut.

Ketujuh, pemilihan walikota Makassar tahun 2018 juga berada dalam kontek sosial yang tinggi. Fenomena kemenangan kolom kosong menjadi bukti bahwa masyarakat pemilih yang sangat heterogen di Makassar juga memiliki diferensiasi sosial yang tinggi pula. Efek pengetahun, informasi dan pesan yang tersampaikan kepada pemilih melalui mobilisasi media sosial, menyebabkan sebagain besar pemilih tidak lagi mempersoalkan hubungan etnisitas ataupun agama, namun mereka aktif berpartisipasi dengan satu tujuan tidak untuk memenangkan calon tunggal yang dianggap tidak memiliki kapabilitas yang kuat dalam memimpin kota Makassar.

\section{Kesimpulan}

Melalui rangkaian uraian di atas disimpulkan bahwa kemenangan kolom kosong pada Pilkada Makassar 2018 didukung oleh dua kekuatan politik, yaitu tim sukses DIAmi dan kelompok non-partai. Dua kekuatan secara aktif berkampanye menggunakan pola pengarahan massa dengan berbagai cara. Salah satu pola pengarahan massa yang dilakukan dan dianggap banyak memberikan pengaruh besar atas kemenangan kolom kosong yaitu pola pengarahan massa tidak langsung melalui media sosial grup Facebook, yaitu Gerakan Kotak Kosong Makassar (GKKM) yang beranggotakan 1.013 akun. Baik tim sukses DIA-mi dan GKKM memiliki berbagai kegiatan dalam mendukung kolom kosong, yakni spanduk kolom kosong dipasang di lorong-lorong setiap kecamatan, pertemuan membahas kolom kosong, baju kolom kosong, dan posterposter lainnya.

\section{DAFTAR PUSTAKA}

Rini, Wafia Silvi Dhesinta. "Calon Tunggal Dalam Pemilhan Umum Kepala Daerah Dan Konsep Demokrasi (Analisis Terhadap Pemiihan Kepala Daerah Kabupaten Blitar Tahun 2015)" dalam Jurnal Cita Hukum, Vol. 4, No. 1 (2016), h. 87-104.

Nugroho, Kris. "Ikhtiar Teoritik Mengkaji Peran Partai dalam Mobilisasi Politik Elektoral" dalam Masyarakat, Budaya dan Politik, Vol. 24, No. 3 (2011), h.112. 
Elwan, La Ode Muhammad. "Model dan Dampak Mobilisasi Politik Pemilihan Kepala Desa (Studi Kasus: Desa Bontomatinggi Kabupaten Maros Sulawesi Selatan Tahun 2016)" dalam Journal Publicuho, Vol. 1, No. 4 (2019), h. 1-17.

Permadi, Bagus. "Kontestasi Pilkada DKI Jakarta Tahun 2017: Studi Tentang Jejaring Mobilisasi Politik Pencalonan Ahok-Djarot" dalam Jurnal Politik Muda, Vol. 6, No.1 (2017), h. 7-13.

Mochtar, Hilmy. Demokrasi Dan Politk Lakol Di Kota Santri. Malang: UB Press, 2011.

Pujo, Asmoro. "Sepak Bola dan Politik: Mobilisas Massa Suporter PSIS Semarang Oleh Alamsyah Satyanegara Sukawjaya Untuk Pemenangan Pemilu Legislatif Tahun 2014”. Skripsi. Semarang: Universitas Wahid Hasyim Semarang, 2018.

Firdausi, Cindy Indira. "Jaringan Politik Dalam Pilwali Surabaya Tahun 2015 Studi Peran Pemuda PIS Dalam Mendukung Pencalonan Risma-Whisnu" dalam Jurnal Politik Muda, Vol 6, No 1 (2017), h. 27-33.

Furchan, Arief. Pengantar Metode Penelition Kualitatif. Surabaya: Usaha Nasional, 1992.

Suyitno. Metode Peneitian Kualitatif Konsep, Prinsip don Operasionainya. Tulungagung: Akademia Pustaka, 2018.

Prihatsanti, Unika, Suryanto \& Wiwin Hendriani. "Menggunakan studi kasus sebagai metode ilmiah dalam Psikologi" dalam Buletin Psikologi, Vol. 26, No. 2 (2018), h. 126-136.

Yuliawan, Teddi Prasetya \& Fathul Himam. "The Grasshopper Phenomenon: Studi Kasus Terhadap Profesional yang Sering Berpindah-pindah Pekerjaan" dalam Jurnal Psikologi, Vol 34, No. 1 (2007), h. 76-88.

\section{Wawancara}

Almalik, Anggota Grup GKKM, wawancara, 2 Mei 2019.

Fajar, Dosen UIN Alauddin Makassar, wawancara, 28 Juni 2019.

Igaruddin, Anggota dari Relawan Kolom Kosong (REWAKO), wawancara, 22 Juni 2019.

Muhammad Saiful, Sosiolog Politik UNM, wawancara, 28 Juni 2019.

Reza, Anggota Crisis Center Kolom Kosong, wawancara,15 Mei 2019. 